\title{
The Society for Anaerobic Microbiology
}

VIII International Symposium will be held at Churchill College, Cambridge on 22nd-24th July, 1993

\section{Provisional programme}

Thursday, 22 July p.m. Gram-positive anaerobes in periodontal disease (joint meeting in conjunction with the Oral Microbiology and Immunology Group) Chairman: W. Wade (Cardiff); Speakers: J. Greenman (Bristol), U. Gobel (Freiburg)

Friday, 23 July a.m. Anaerobic intestinal ecosystems. Chairman: M. Hudson (CAMR, PHLS); Speaker: C. Stewart (Aberdeen)

Ecology and epidemiology of $C$. difficile. Chairman and keynote speaker: S. P. Borriello (Nottingham); Speakers: T. V. Riley (Perth), B. D. Cookson (CPHL)

p.m. Broad-spectrum antibiotics and anaerobes. Chairman and keynote speaker: E. Goldstein (Los Angeles); Speakers: T. J. M. van Steenbergen (Amsterdam), G. Reysset (Paris)

Saturday, 24 July a.m. DNA technology and anaerobes. Chairman: B. Wren

(London); Speakers: C. von Eichel-Streiber (Mainz), S. Cole (Paris)

The Symposium will include free oral presentations and posters and the Proceedings will be published.

\section{Further information may be obtained from:}

Dr J. Brazier, Anaerobe Reference Unit,

Department of Medical Microbiology and Public Health Laboratory, University Hospital of Wales, Heath Park,

Cardiff CF4 4XN

Tel. Cardiff (0222) 742171

Fax. (0222) 751729

The Society for Anaerobic Microbiology is grateful to the Federation of European Microbiological Societies (FEMS) for sponsoring the attendance of young European scientists at this meeting by funding a series of bursaries. Young research workers in any field of anaerobic microbiology who wish to apply for financial assistance to attend the Symposium should apply to the SAM at the above address.

\section{OAKLEY LECTURESHIP}

The CL Oakley lecturer will be nominated by the Microbiology Section of the Pathological Society to speak at the winter meeting of the Society in January 1994. Any member wishing to put forward the name of a possible recipient of this lectureship should submit this in writing to Dr Rosamund Williams at the Pathological Society, 2 Carlton House Terrace, London SW1Y 5AF.

\section{ERRATUM}

\section{Jose AWL, Chatterton JMW, Evans R, Ho-Yen DO.}

Toxoplasma polymerase chain reaction on experimental blood samples. J Med Microbiol 1993; 38: $38-43$.

Page 41, Table II footnote should read: *Antibody detected in mice 6 weeks after inoculation with rat or mouse blood. Results of water washed leucocytes compared with those without water wash (in parentheses). 